\title{
ALKALOIDS OF Buxus hyrcana
}

\section{ISOLATION OF BUXPIINE AND OF BASE II}

\author{
G. M. Orazmuradov and A. M. Aliev
}

UDC $547 / 945$

Continuing a study of the alkaloids of Buxus hyrcana Pojark, from the leaves collected in the flowe ring phase (April, 1976) in addition to those isolated previously [1-4], by ethanolic extraction we have obtained another two alkaloids.

The combined alkaloids (25 g) were chromatographed on a comumn of alunina (here and below, activity grade II) with elution by benzene-ethanol $(19: 1)$.

On TLC, fractions 8-14 each gave three spots with the same $R_{f}$ values, and they were therefore combined, and the dry residue after the evaporation of the solvent (4 g) was rechromatographed on a column of alumina and was eluted with benzene. From benzene fractions 4-6 (150 ml), as the solvent evaporated, a crystalline base deposited with $\mathrm{mp} 171-172^{\circ} \mathrm{C}$ (benzene), $[\alpha]_{\mathrm{D}}^{24}+157^{\circ}$ (c 0.31 ; chloroform) which was identical with the product of the methylation (by Hess's method) of buxtauine-buxpiine (melting point, IR spectra, $R_{f}$ values [5-7].

This is the first time that buxpiine has been isolated from a plant of the domestic flora. The dry residue $(6 \mathrm{~g})$ obtained by eliminating the solvent from fractions 8-14 was rechromatographed on a column of alumina with elution by benzene-ether $(6: 4)$. Fractions $7-10$, after evaporation of the solvent, gave a crystalline substance, base (II), with $\mathrm{R}_{\mathrm{f}} 0.64$ [TLC; $\mathrm{Al}_{2} \mathrm{O}_{3}$; benzene-ethanol (9:1) system]; after recry stallization from acetone

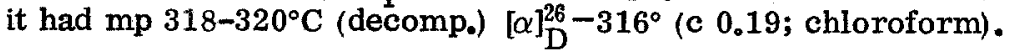

The IR spectrum of (II) showed absorption bands at $\left(\mathrm{cm}^{-1}\right) 720,810(\mathrm{C}=\mathrm{C}), 1030,3470(\mathrm{OH}), 1690(\mathrm{C}=\mathrm{O})$, 1458, 3038 (methylenecyclopropane system), 1200, 1380 (gem-dimethyl groups), and $1145,2930\left(-\mathrm{CH}_{2}-,-\mathrm{CH}_{3}\right)$.

Base (II) differs markedly from all the alkaloids isolated previously from various species of the family Buxaceae by its high melting point and specific rotation, and we therefore consider that it is a new base for this family.

\section{LITERATURE CITED}

1. A. M. Aliev and G. M. Orazmuradov, Khim. Prirodn. Soedin,, 409 (1974).

2. A. M. Aliev and G. M. Orazmuradov, Khim. Prirodn, Soedin., 808 (1974).

3. A. M. Aliev and G. M. Orazmuradov, Proceedings of the Second All-Union Conference of Pharmacists [in Russian], Riga (1974), p. 212.

4. G. M. Orazmuradov, First Congress of Pharmacists of Azerbaidzhan (Abstracts of Lectures) [in Russian], Baku (1976), p. 124.

5. Z. Voticky, J. Tomko, L. Dolejs, and V. Hanus, Collect. Ozech. Chem. Commun., 11, 3705 (1965).

6. J. Tomko, Z. Voticky, V. Paulik, A. Vassova, and O. Bauerova, Chem. Zvest., 18,721 (1964).

7. Z. Voticky, J. Tomko, et al. Tetrahedron Lett., No. 40, 3579 (1965).

N. Narimonov Azerbaidzhan State Medical Institute. Institute of Chemistry of the Academy of Sciences of the Turkmen SSR, Ashkhabad. Translated from Khimiya Prirodnykh Soedinenii, No. 4, pp. 582-583, July-August, 1977. Original article submitted April 14, 1977. 